DOI: http://doi.org/10.21698/simi.2018.fp40

\title{
ASSESSMENT OF DRINKING WATER QUALITY FROM TREATMENT PLANTS AND CONSUMERS
}

\author{
Mariana Popescu ${ }^{1,2}$, Diana Puiuu, ${ }^{1,3}$, Madalina Mihalache ${ }^{1,4}$, Vasile Ion Iancu ${ }^{1,4^{*}}$, Marius \\ Simion $^{1,4}$, Marcela Antoaneta Niculescu ${ }^{1}$, Daniel Manolache ${ }^{1,4}$, Liliana Cruceru ${ }^{1}$ \\ ${ }^{1}$ National Research and Development Institute for Industrial Ecology-ECOIND, 71-73 \\ Drumul Podu Dambovitei, district 6, 060652, Bucharest, *vasileiancu10@gmail.com, Romania \\ ${ }^{2}$ Titu Maiorescu University of Medicine and Pharmacy, Faculty of Pharmacy, 22 \\ Dambovnicului, 040441, Bucharest, Romania \\ ${ }^{3}$ University of Bucharest, Faculty of Biology, 91-95 Splaiul Independenei, 050095, Bucharest, \\ Romania \\ ${ }^{4}$ University Politehnica Bucharest, Faculty of Applied Chemistry and Materials Science, 1-7 \\ Polizu Street, 011061, Bucharest, Romania
}

\begin{abstract}
The present study investigated the quality of potable water that was taken from the treatment plants in three counties from Romania (Ialomița, Gorj and Tulcea) for a two-year period (2016 and 2017). A series of organic and inorganic indicators have been analyzed in the drinking water from the respective locations.

Out of the 37 samples collected in Ialomița county in 2016, the following indicators have exceeded the maximum admissible concentrations (MAC): sodium in $8 \%$ of the total samples, nitrogen in $38 \%$, copper in $27 \%$, manganese in $5 \%$, iron, nickel and chromium in 3\% of the samples. In Gorj County, samples from 25 locations were analyzed during 2017. Exceedings of MAC were recorded for hardness in 36\% of the samples, for boron in $16 \%$, for ammonium, iron and manganese in $12 \%$, for sodium and for chloride in 4\% of samples. In 2017 a total of 33 samples were analyzed in Tulcea County; the following indicators have exceeded MAC trihalomethanes and iron in 3\% of samples and manganese and fluorides in $9 \%$ of samples.

For the analyzed indicators that exceeded the maximum admissible concentrations a database including the physical-chemical characteristics of drinking water at the exit from the treatment plants was created.
\end{abstract}

Keywords: admissible values, drinking water, physical-chemical indicators, treatment plants

\section{Introduction}

The term commonly used for water intended for human consumption is drinking water. This is considered to be any type of water in its natural state or after treatment, which is used for drinking, food preparation or other domestic purposes, regardless of its source and its providing through distribution network, tanks, bottles or other types of containers (Ordinance no. 22/2017).

In order to obtain drinking water in accordance with the requirements of the law in force, used for human or industrial consumption, it is necessary that surface, underground and marine waters to be treated in order to remove impurities and pollutants of organic and inorganic origin, microorganisms existing in water 


\section{INTERNATIONAL SYMPOSIUM "THE ENVIRONMENT AND THE INDUSTRY", SIMI 2018, PROCEEDINGS BOOK}

naturally occurring or due to accidental pollution (Radulescu 2017, Spataru 2017); it is not to be neglected the contribution due to the level of air pollution by the intake of wet and dry deposits (Petrescu et al 2017, Bucur et al 2010).

A drinking water required for human or industrial consumption, in order to meet quality standards, must be treated by a succession of operations and unit processes, where the degree of treatment varies function of the quality of the source used and the requirements of the consumer (Galaon et al 2017).

A drinking water is considered to be of adequate quality when the set values for the tested parameters (microbiological and physical-chemical indicators) are in accordance with the maximum admissible concentrations (MAC) imposed by legislation for different types of sampling points (distribution network, the consumers tap, points where water is taken up in various production processes) (Ordinance 22/03.09.2017)

\section{Materials and Methods}

\section{Sampling}

During 2016, samples of drinking water were collected and analyzed from a number of 37 locations in Ialomita county. In 2017, in Gorj County, a number of 25 samples were taken, while in Tulcea County a number of 33 samples were taken from different sampling locations. Samples were collected in glass or plastic recipients function of the organic or inorganic nature of the tested parameters.

\section{Methods}

For all samples, a series of organic and inorganic indicators were analyzed by standardized physical-chemical methods: arsenic, benzene, benzo (a) pyrene, boron, bromate, cadmium, total cyanide, free cyanide, total chromium, 1,2-dichloroethane, fluoride, PAH, mercury, nickel, nitrate, nitrite, total pesticides, organochlorine pesticides, organophosphate pesticides, triazine pesticides, lead, selenium, antimony, tetrachloroethene, trichloroethene, trihalomethanes, aluminum, ammonium, total organic carbon (TOC), chlorine, free residual chlorine, conductivity, color, total hardness, iron, manganese, oxidation (CCO-Mn permanganate index), $\mathrm{pH}$, sodium, sulfates, sulfides, hydrogen sulphide, turbidity and zinc.

\section{Results and discussions}

For the 37 samples taken in 2016 in Ialomița county, most of the analyzed indicators were situated below the maximum admissible concentrations imposed by the Ordinance no. 22/2017 for amending and completing the Law no. 458/2002 on the quality of drinking water. Exceedances were recorded for nitrates (in 38\% of samples), sodium (in $8 \%$ of samples), copper (in 27\% of samples), manganese (in $5 \%$ of samples), iron, nickel and chromium (in 3\% of samples). In fig. 1 are represented the exceedances of the maximum admissible concentrations for nitrates, sodium, copper, manganese, iron, nickel and chromium for the corresponding locations. 


\section{INTERNATIONAL SYMPOSIUM "THE ENVIRONMENT AND THE INDUSTRY", SIMI 2018, PROCEEDINGS BOOK}
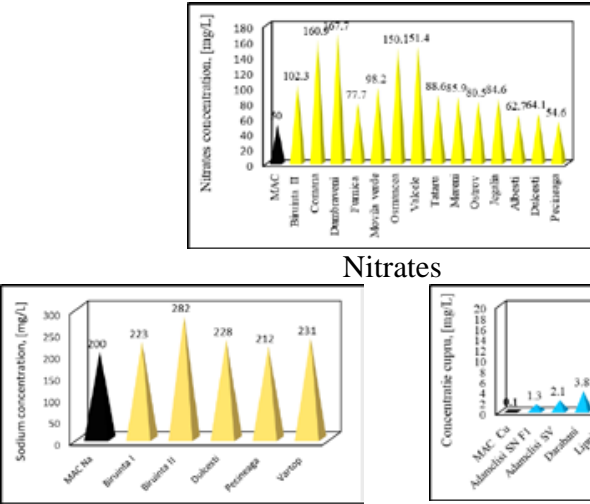

Sodium

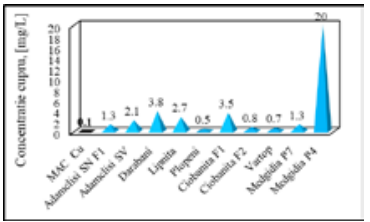

Copper

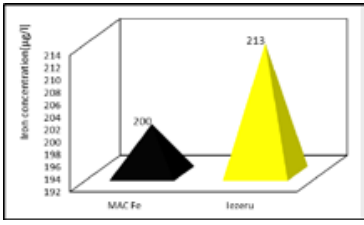

Iron

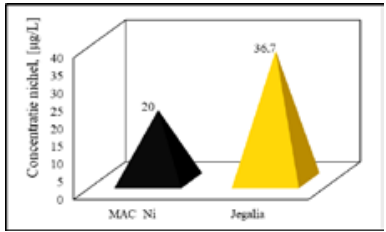

Nickel

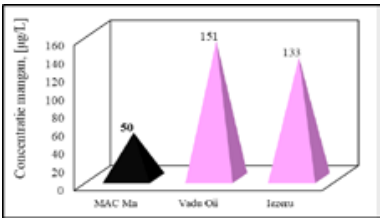

Manganese

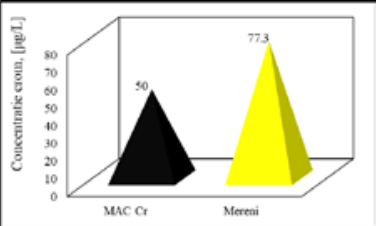

Chromium

Figure 1. Exceeding maximum admissible concentrations for nitrates, sodium, copper, iron, manganese, nickel and chromium in samples from Ialomita county

In 2017, samples were taken from 25 locations in Gorj County. Most of the analyzed indicators were situated below the maximum admissible concentrations given by Ordinance no. 22/2017 for amending and completing the Law no. 458/2002 on the quality of drinking water. Higher values than the maximum admissible concentration were recorded for hardness, ammonia, iron, manganese, sodium and chloride. The total hardness was below the admissible limit in 36\% of the samples. Exceedances of the maximum admissible concentration were recorded for ammonium and boron in $16 \%$ of samples, iron and manganese $12 \%$ and sodium and chlorides for $4 \%$ of the total of 25 samples. In fig. 2, are represented the noncompliance results compared with the law values for total hardness, ammonium, iron, manganese, sodium, chloride and boron corresponding to the related locations. 


\section{INTERNATIONAL SYMPOSIUM "THE ENVIRONMENT AND THE INDUSTRY", SIMI 2018, PROCEEDINGS BOOK}

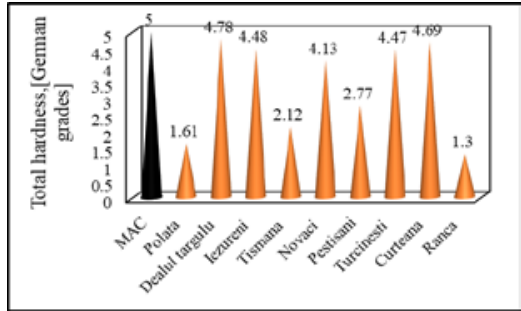

Total hardness
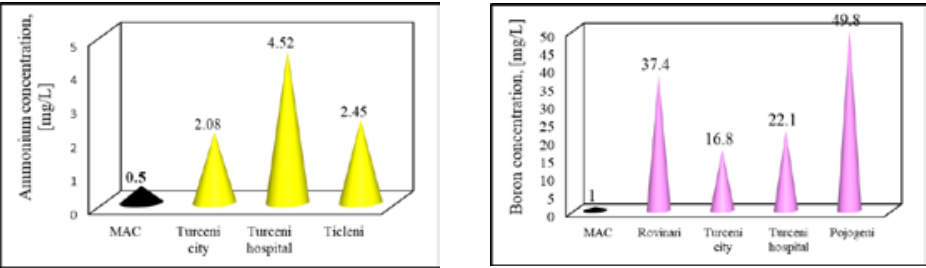

Ammonium
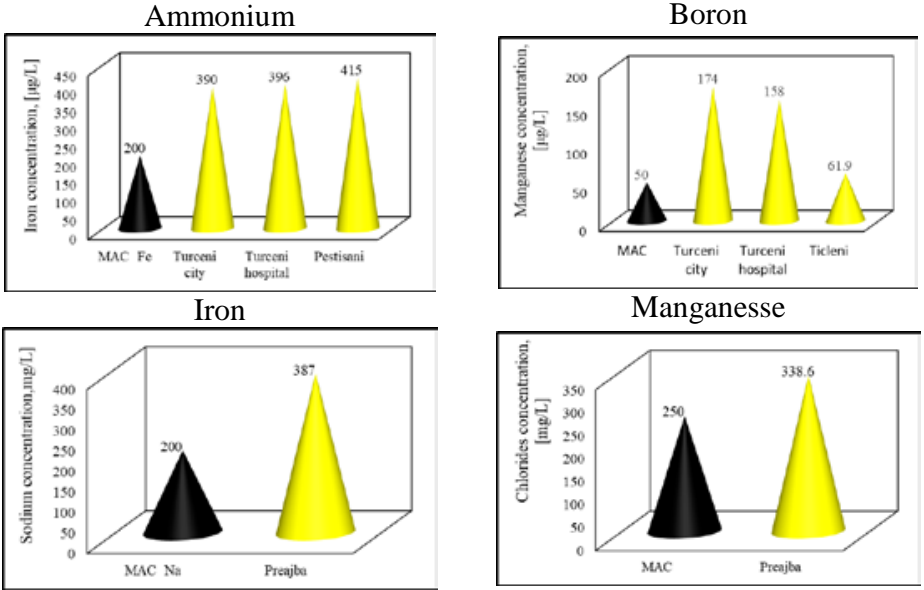

Chlorides

Sodium

Figure 2. Exceeding maximum admissible concentrations for total hardness, ammonium, boron, iron, manganese, sodium and chlorides in samples from Gorj county

Most of the indicators analyzed for the 33 samples taken in 2017 in Tulcea County were situated below the maximum admissible concentrations under Ordinance no. 22/2017 for amending and completing the Law no. 458/2002 on the quality of drinking water. Overdosed values were recorded for manganese and fluorides at $9 \%$ of samples, trihalomethanes and iron in 3\% of samples. Fig. 3 shows the exceedance of the maximum admissible concentrations for trihalomethanes, fluorides, iron and manganese corresponding to their respective locations. 

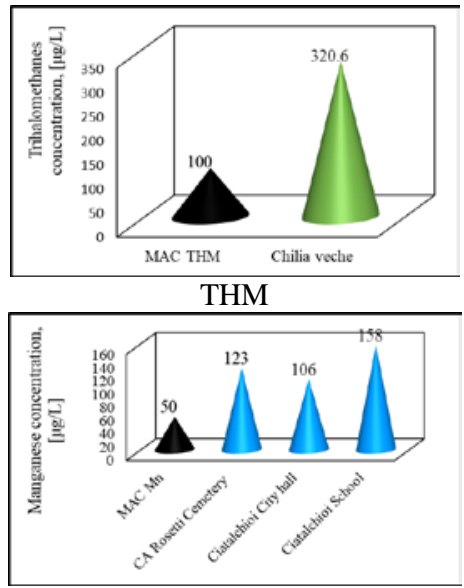

Manganese

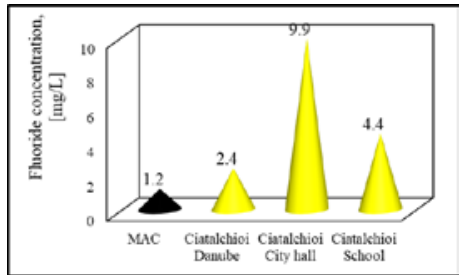

Fluoride

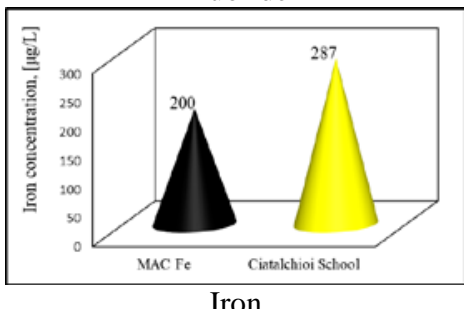

Iron

Figure 3. Exceeding maximum admissible concentrations for trihalomethanes, iron, manganese and fluorides in the mentioned locations

\section{Conclusions}

Following the monitoring of drinking water quality in Ialomiţa, Gorj and Tulcea counties,the majority of the analyzed organic and inorganic indicators from the drinking water samples studied were below the maximum admissible limits stipulated by the Ordinance no. 22/2017 for amending and completing the Law no. $458 / 2002$ on the quality of drinking water.

For all locations in the three counties (Ialomita, Gorj and Tulcea) where exceedances of the maximum admissible values for different indicators were found, for exemple sodium, iron and manganese, the waters do not meet the drinking standards.

\section{References}

Bucur, E, Ionita, L, Petrescu, M 2010, 'Consideration concerning impact assessment of pollution with breathable PM 2.5 particulate matters. Part 1. Pollution monitoring in urban areas with intense road traffic, Journal of Environmental Protection and Ecology, vol. 11, no. 3, pp. 809-814.

Galaon, T, Petre, J, Iancu, V, Cruceru, L, Niculescu, M, Chiriac, LF, Puiu, DM \& Mihalache, M 2017, 'Detection of cytostatic drugs in municipal waste water and their transfer to surface water', $20^{\text {th }}$ International Symposium "The Environment and The Industry", SIMI 2017, National Research and Development Institute for Industrial Ecology ECOIND, Bucharest, pp. 229236.

Ordinance no. 22/2017 for amending and completing the Law no. 458/2002 on the quality of drinking water.

Petrescu, M, Bucur, E, Diodiu, R, Bratu, M, Serbanescu, A, Barbu, ME 2017, 'Chemical characterization of wet depositions in urban and rural area', $20^{\text {th }}$ International Symposium "The Environment and The Industry", SIMI 2017, National Research and Development Institute for Industrial Ecology ECOIND, Bucharest, pp. 213-220. 


\section{INTERNATIONAL SYMPOSIUM "THE ENVIRONMENT AND THE INDUSTRY", SIMI 2018, PROCEEDINGS BOOK}

Radulescu, V 2017, 'Control of inorganic and organic contamination, asessment of water quality in hydropower lakes on Jiu river', $20^{\text {th }}$ International Symposium "The Environment and The Industry", SIMI 2017, National Research and Development Institute for Industrial Ecology ECOIND, Bucharest, pp. 221228.

Spataru, P 2017, 'Influences of organic ammonium derivatives on the change of concentrations of $\mathrm{NH}^{4+}, \mathrm{NO}^{2-}, \mathrm{NO}^{3-}$ in river water', $20^{\text {th }}$ International Symposium "The Environment and The Industry", SIMI 2017, National Research and Development Institute for Industrial Ecology ECOIND, Bucharest, pp. 265-271. 